determining the presence of any vital activity in them. Other communications by Prof. Moore dealt with the action of ultra-violet light upon solutions of organic substances, and with the presence of iron salts in the colourless portion of the chloroplast, and the mechanism of photo-synthesis by iron salts. $\mathrm{Mr}$. Halcro Wardlaw, a science research scholar of Sydney University, described the results of a series of analyses of the deposit obtained from milk by spinning it in a centrifuge, and Dr. Burton Bradley contributed some notes on the symbiotic activities of coliform and other organisms on media containing carbohydrates.

The last day's proceedings of the section in Sydney embraced a lengthy programme, but most of the papers were taken as read, and the section thereafter joined those of chemistry and agriculture in a discussion upon metabolism. Among the subjects brought before the section, and of which abstracts were printed, were papers by Prof. T. H. Milroy on changes in the reaction of milk under different conditions as determined by the estimation of hydrogenion concentration bv the electrometric method, and measurements of the variations of the hydrogen-ion concentration of the blood. Prof. P. T. Herring contributed papers upon the relative activity of the pars intermedia and pars nervosa of the ox pituitary, and upon the influence of the thyroid upon the activity of the suprarenals and pituitary body. In the latter communication the chief point of interest was the loss of chromaffine-substance, and corresponding diminution of activity, of the medulla of the suprarenals which rapidly follow thyroidectomy; thyroid-feeding, on the other hand, though pushed to an extreme, has no such effect. Dr. H. G. Chapman presented a paper on the freezing point of the laked red blood corpuscles of man and some domesticated animals, and Dr. C. Shellshear a paper on precipitin reactions in pathological human urines.

Several papers on psychological subjects appeared on the programme, but it was found impossible to take them. A feature of the sectional business in both Melbourne and Sydney was the large and varied contributions by local members, evincing evidence of the activity of the physiological departments in the universities.

\section{AGRICULTURE AT THE BRITISH ASSOCIATION.}

$T$ HE paramount importance of agriculture in Australia rendered the proceedings of Section $M$ of special local interest, and the addresses and papers were arranged to deal with subjects of real significance in that country. The two addresses delivered by the president, Mr. A. D. Hall, attracted large audiences both at Adelaide and Brisbane. They were read at sessions of the whole association, and formed as valuable a contribution to Australia's needs as agricultural science and research could well have provided.

The meetings of the section at Melbourne were devoted to the subjects of irrigation, dry farming, animal breeding, and milk supply, all of which were selected in view of their importance to the Australian agriculturist. The papers on irrigation were read at a joint meeting, with Section G (Engineering), and an account of the discussion has been given in the report of the proceedings of that section (November 5, p. 266).

An excellent paper by Dr. Lyman J. Briggs on dry farming investigations in the United which has been carried on for many years in America on this subject. Dr. Briggs illustrated his paper with maps and diagrams, and pointed out the differences NO. $235 \mathrm{I}$, VOL. 94] which exist between the problems in America and those in Australia. Differences in the distribution and amount of the rainfall and in the nature of the soil indicate the necessity for much investigation into the special problems of each district. A more restricted problem of special Australian interest, "The Ten-inch Line of Rainfall," was discussed by Dr. T. Cherry, who pointed out that the rainfall throughout the southern third of the continent is almost exclusively of the winter type, and that the winter temperatures are high enough to keep the ordinary cereals growing during these months. The chief problem which in this instance has now to be solved is to devise methods by which sheep and cattle can also be profitably kept on the wheat farms in the ro-in. line of rainfall, the area already having been proved very suitable for wheat.

The very high evaporation factor, which in Western Australia is four to six times greater than the rainfall, adds to the difficulty of maintaining the soil moisture. Prof. J. W. Paterson contrasted this evaporation with that in England, which is only about one-half of the annual rainfall. He also stated that the sandy soils in these dry districts are an advantage, as they are able to absorb all the rain which falls and can yield up the retained moisture more completely to the plant than more absorbent clay soils. The movement of air and water within the soil is dependent on the sizes and distribution of the free spaces between the particles, a subject dealt with by Dr. Heber Green, who spoke of the capillary power of soils and of the experiments and calculations which he had made on this subject.

Perhaps no branch of scientific research is likely to be of more direct practical value than the investigations into the laws of inheritance. In the field of animal breeding Mr. P. G. Bailey represented the Cambridge school, and reported the progress of experiments conducted on the inheritance of wool characters in a cross made between two Merino rams from Western Australia and twenty Shropshire ewes at Cambridge. He also contributed a paper on size inheritance in poultry, a subject which bids fair to yield results of practical importance to an industry which is assuming large proportions in Australia.

The improvement of the quantity and quality of milk yield has received a great impetus in late years by the keeping of milk records and the gradual elimination of the less productive cows from herds. The development of this work in England, Scotland, and Ireland was reviewed by Dr. A. Lauder. Dr. S. S. Cameron and Mr. O'Callaghan spoke of developments in this direction in Australia.

The high cost and scarcity of labour in Australia has forced the development of milking machines. $\mathrm{Mr}$. Archer estimated that in Victoria alone 2000 farmers had been supplied with milking machines, and that about fourteen different makes were in use. The principal local feature is the conduit system, in which the milk is conveyed through metal pipes to a tank in the dairy, thus saving the labour of carrying the milk.

The scientific comparison of the bacteriological purity and keeping qualities of milk obtained from eleven different types of machine at trials arranged by the Royal Agricultural Society of England formed the subject of a paper by Dr. R. Stenhouse Williams, Mr. J. Golding, and Mr. J. Mackintosh. The difficulties in cleaning many of the machines, especially those fitted with long rubber tubes, is one of the chief drawbacks to their employment under existing conditions on many farms.

A visit to the State experimental farms in Australia is sufficient to show the very great importance attached to the subject of cereal breeding. Not only is a large 
area of these many farms devoted to experiments on this subject; but the keen interest taken by the staffs in scientific investigation in other parts of the world and the enthusiasm in the work of William Farrer and other Australian investigators cannot fail to impress the visitor. A whole meeting at Sydney was not sufficient to exhaust the papers and discussion on cereal breeding. The papers read were as follows:"The Migration of Reserve Material to the Seeds in Barley, considered as a Factor in Production," by Mr: E. S. Beaven; "Wheat Improvement in Australia," by Mr. F. B. Guthrie; "William Farrer's Work, Methods, and Success : a Short Sketch," by Mr. J. T. Pridham; "Wheat Breeding in Australia," by Mr. A. E. V. Richardson. Prof. Bateson, Mr. A. D. Hall, Prof. T. B. Wood and others took part in the discussion. The value of the Mendelian theory in providing a speedy and certain method for the practical man, and in directing his problems on scientific lines was illustrated by Mr. Beaven's work on barley. $\mathrm{He}$ showed that the ratio of the dry matter accumulated in the seed, to the total dry matter of the plant when fully ripe, frequently influences the produce of grain to a greater extent than any other factor. This "coefficient of migration" differs with different races of barley within the gross productive power which is $a$ product of the environment.

A joint discussion with Section B (Chemistry) on metabolism, which took place at Sydney, will be reported in an article on the work of that section. Other papers contributed included "Flax as Paying Crop," by Mr. C. P. Ogilvie; "Bacterial Toxins in Soil," by Dr. Greig Smith; "The Estimation of Condition in Cattle," by Mr. J. A. Murray; "A Review of Work on Soil Inoculation," by Dr. H. B. Hutchinson, and Mr. J. Golding; and "The Effects of Caustic Lime and Chalk on Soil Fertility," by Dr. H. B. Hutchinson and Mr. K. MacLennan.

Highly satisfactory as they were, the proceedings of the section in session cannot be taken as a measure of the work achieved in 1914, for the unique advantages which members of the section gained by a visit to so rich and varied a field of agricultural endeavour cannot fail to bear fruit rich in its benefit to the science of agriculture.

It is only possible briefly to refer to the numerous and valuable agricultural excursions which were specially arranged, not only to meet the wishes of the whole section, but also to enable individual members to make independent visits to farms and districts where the branches of agriculture in which they had specialised were seen to the best advantage.

In Western Australia the latter type of excursion prevailed, and, under the personal guidance of $\mathrm{Mr}$. W. Catton Grasby, Mr. J. L. Sutton, Prof. Paterson, Dr. Stoward, and Mr. A. E. Weston, visits were made to see the great developments which have recently taken place in corn growing, fruit growing, and other departments of agriculture in the great south-west area of this promising State.

From Adelaide excursions were made to Angaston, Seppeltsfield, and Tanunda. Mr. Charles Angas entertained a large party to lunch at Angaston. Vineyards and the agricultural land in the neighbourhood were afterwards visited. Roseworthy Agricultural College was the objective of a most interesting excursion from Adelaide. The instruction given to students is of a very practical nature, the buildings and laboratories are good, and the farm very well laid out in experiments on crops and stock. The introduction of Berseem (Trifolium alexandrium) on an irrigated plot of four acres had proved very successful, twenty-five cows having been kept on the produce of the plot for five months during the winter, the yield of green food being 36 tons per acre.

In Victoria the principal agricultural excursion was to the Central Research Farm at Werribee. Although only started in 1912 , this farm of more than 1000 acres is admirably laid out in experiments on dry farming, irrigation, and live stock. The organisation was quite a model for similar institutions; a large party was conducted over it in a most thorough manner, all the experiments being ably explained by the staff and authorities from Melbourne.

From Sydney a three days' excursion was arranged which included visits to the Wagga Experiment Farm, Mr. Anthony Brunskill's I2,000 acre farm, and two days in the interesting Murrumbidgee irrigation area, including the Yanco Government Irrigation Farm and Works. Motor-cars wore provided, and nights were spent in a special sleeping car.

$\mathrm{Mr}$. Wade, who himself conducted the party over the irrigation area, gave a lecture and showed lantern slides and plans of this great scheme, which will provide nearly 7000 farms and support a population of roo,ooo people on land. which until the scheme was taken up by the Government was used as sheep runs. The famous Hawkesbury Agricultural College was also visited from Sydney, where accommodation for 200 resident students is provided; the farm comprises some $344^{\circ}$ acres of land. All branches of farming, esnecially the orchard, dairy, piggery, and poultry farm, were well worth a visit.

The cultivation of sugar cane and a sugar mill in full work was inspected at Nambour, Queensland, by a large party, and opportunities were afforded for smaller parties to sec the work on the eradication of the prickly-pear, and to visit large sheep farms, etc.

The most striking feature in the visits to experimental farms in most parts of Australia was the response shown by the crops to phosphatic manures, even when, as is the practice, very small dressing were applied with the combined manure and seed drill. In one case in Western Australia $30 \mathrm{lb}$. of superphosphate added per acre had doubled the yield of wheat (9 bushels raised to 18 ). Sixty to $80 \mathrm{lb}$. of superphosphate per acre were commonly used in this excellent drill.

The section met with the greatest kindness and hospitality on all sides, and it is invidious to particularise amongst such a number of generous and indefatigable hosts, but special thanks are due to $\mathrm{Mr}$. W. Hutchinson, Minister of Agriculture for Victoria, Dr. Cameron, Dr. Cherry, and Mr. Richardson, of Melbourne, and to Prof. R. D. Watt, of Sydney, fo: the part they took in carrying out the many and valuable excursions

\section{BUDGETS AND STUDENTS OF UNIVER- SITIES AND UNIVERSITY COLLEGES IN RECEIPT OF STATE GRANTS.}

THE reports for the year I912-I3 from those universities and university colleges in Great Britain which are in receipt of grant from the Board of Education have been published in two Blue-book (Cd. 76I4 and Cd. 76r5). The tabular matter, which precedes the separate reports from the places of highe education dealt with, contains detailed information as to the income and expenditure of the various institutions concerned. The following summaries have been compiled from the tables, and make clear the amount available for higher education and research in the universities and university colleges receiving Treasury grants, and how the income is expended.

NO. $235 \mathrm{I}$, VOL. 941 